\title{
Bittra tårar och gudomlig förtröstan
}

\author{
Uttryck för sorg och tröst i svenskspråkiga ståndspersoners brev i Finland \\ $1808-1852$
}

LÖRDAGEN DEN 24 OKTOBER I835 hölls begravningen för friherrinnan Catarina Elisabet von Born (I793-I835, född von Morian) i Åbo domkyrka. Hennes man, Samuel Fredrik von Born (I782-1850), beskrev tillfället i ett brev till parets två frånvarande söner; han berättade att kyrkan var "illuminerad rikeligen" och att "en herrlig sorgmusik som frapperade alla" uppfördes för de gäster som samlats till den av domprost Gustaf Gadolin förrättade jordfästningen. Friherrinnan hade avlidit ett par dagar tidigare av lungsot, en av I80o-talets vanligaste sjukdomar. ${ }^{1}$ De frånvarande sönerna, Carl Fredrik (I8I3-1867) och Johan August von Born (I815-I878), befann sig på hemväg från sin grand tour i Europa. Deras far skrev till dem om den olycka som "strängt verkadt på min egen och syskonens samt Mad[emoiselle] Stenborgs sinnesförfattning". ${ }^{2}$ "Badande i tårar" läste han sedan sina söners bekräftelser på att de mottagit dödsbudet och tillade: "Måtte Försynen förunna Eder tillräkelige Krafter att bära saknaden, och sorgen." ${ }^{3}$

Friherre von Borns beskrivning av den sorg som drabbade familjen är bara ett av många exempel på uttryck för sorg och tröst som finns bevarade i brev och dagböcker från det tidiga I8oo-talet. Även om bättre tillgång till mat, inokuleringen mot smittkopporna som kommit

I. von Borns sjukdom och död beskrivs i Evelina Knipström, "Hvad är vårt lif då bälsan saknas?" Sjukdom och död i kvinnliga ståndspersoners korrespondens I808-I852 $i$ Finland, opublicerad avhandling pro gradu, Helsingfors universitet 2015, http:// urn.fi/URN:NBN:fi:hulib-20I70I3IIIg6.

2. S.F. von Born till C.F. och J.A. von Born, $27 /$ ıo 1835, Äldre Sarvlaks arkiv, Svenska litteratursällskapet i Finlands arkiv (SLSA).

3. S.F. von Born till C.F. och J.A. von Born, I4/Ir I835, Äldre Sarvlaks arkiv, SLSA. 
i gång i slutet av I70o-talet och en längre fredsperiod gjorde att den förväntade livslängden började förlängas i början av I8oo-talet, var barndödligheten fortfarande hög och många män och kvinnor blev änklingar och änkor vid ung ålder. Det var till exempel vanligt att män förlorade sina fruar i samband med förlossningar eller i efterföljande infektioner som barnsängsfeber. ${ }^{4}$ De vanliga sjukdomar som i dag kan botas med antibiotika eller undvikas tack vare vaccin var i många fall fortfarande livshotande, och sjukdomar och död var därmed "triviala delar av hennes [människans] livsvillkor". ${ }^{5}$

Fram till början av I80o-talet var den genomsnittliga förväntade livslängden i Europa ungefär 33 år för män och 36 år för kvinnor. ${ }^{6}$ Detta ledde till en ständig oro för de närståendes hälsa och till att människorna blev väl förtrogna med dödsfall inom den närmsta kretsen. Dödens ständiga närvaro gjorde knappast sorgen lättare att bära, men däremot var behovet av tröst stort, vilket jag också visar i denna studie.

I den här artikeln studerar jag, genom brev skrivna av svenskspråkiga ståndspersoner under tidsperioden $1808-185_{2}$, hur sorg i samband med död och sjukdom förmedlades i brev och hur den genom dessa blev en delad erfarenhet inom närkretsen av familj och vänner. Jag ser känslor som ett tvådelat begrepp: den ena delen är den biologiska, som ligger till grund för vilka känslor människan kan ha, medan den andra är den socialt och kulturellt konstruerade. Den senare styr hur vi uttrycker och lever ut känslan, beskriver den och delar den med andra. Det är denna andra del, som skapas och förändras utifrån kontext och kultur, som här står i fokus.

Mitt syfte är att belysa hur sorg och tröst yttrade sig i korrespondens mellan svenskspråkiga ståndspersoner i Finland i början av I8oo-talet. Jag gör en närläsning av ett urval av brev och ställer följande frågor: Hur uttryckte svenskspråkiga ståndspersoner i Finland sorg i sina brev? Vilka bilder och föreställningar tröstade de varandra med? Vilken var religionens roll i sorgeprocessen för dessa individer? Vilket var det "rätta" sättet att sörja på?

4. Ulla Ijäs, "Yksilö ja yhteisö", Janne Haikari, Marko Hakanen, Anu Lahtinen \& Alex Snellman (toim.), Aatelin historia Suomessa, Helsinki: Siltala 2020, s. 352.

5. Karin Johannisson, Medicinens öga. Sjukdom, medicin och sambälle - historiska erfarenheter, Stockholm: Norstedts 2013, s. 27.

6. Ibid. 
Mitt källmaterial består av brev som ingår i korrespondensen för sex familjer: Aminoff, Crohns, Ehrström, von Born, Europaeus och Möller. I materialet ingår även brev från mor- eller farföräldrar, som i en bredare bemärkelse kan inkluderas i begreppet familj, liksom från andra släktingar och nära vänner. Därför förekommer också andra släktnamn i materialet. Som släktingar räknas här personer från såväl den manliga som den kvinnliga linjen. ${ }^{7}$ Urvalet av brev utgår från två kriterier. För det första är breven skrivna av svenskspråkiga ståndspersoner i Finland som hade en framstående position i samhället tack vare börd, ekonomi eller ämbete. För det andra framkommer berättelser om sorg på ett konkret och detaljerat sätt i breven. Brevskrivarna drabbades alla av dödsfall som påverkade dem och deras närkrets svårt, vilket de också uttryckte och beskrev i sina brev. Ett kännetecknande drag för alla brev är att tonen är familjär och förtrolig.

De brev jag analyserar kan inte ses som privata i modern mening. De skrevs ofta för att läsas högt och många gånger skrevs de också av någon annan än den person som står som avsändare. Mottagaren kunde i sin tur vidarebefordra breven till andra inom sin bekantskapskrets, vilket givetvis påverkade innehållet och ordvalen. Något som bör beaktas i studier av brev är att innehållet inte kan tolkas som en absolut sanning, utan alltid måste analyseras i sin rätta kontext och med beaktande av den föreställda eller faktiska publiken. Vad skribenten valde att ta med $\mathrm{i}$ breven och hur hen beskrev olika händelser och fenomen påverkades av den tilltänkta mottagaren. Därtill färgades innehållet av skribentens värderingar, hens sociala och kulturella bakgrund, och de förväntningar som dessa medförde. ${ }^{8}$

De brevskrivare som jag studerar tillhörde de högsta skikten i samhället, de var alltså ståndspersoner, en kategori som enligt Kaarlo

7. För mer om begreppen familj och släkt, se Kai Häggman, Perheen vuosisata. Perheen ihanne ja sivistyneistön elämäntapa I8oo-luvun Suomessa, Helsinki: Suomen Historiallinen Seura I994, s. 36-42.

8. Kaisa Vehkalahti,"Opitut tunteet, kerronnan kaavat. Kirjeet I9oo-luvun alun koulukotikasvatuksessa”, Maarit Leskelä-Kärki, Anu Lahtinen \& Kirsi Vainio-Korhonen (toim.), Kirjeet ja historiantutkimus, Helsinki: Suomalaisen Kirjallisuuden Seura 20II, s. 23I; Ulla Koskinen \& Anu Lahtinen, "Siskot, veljet ja erityisen hyvät ystävät. Aatelismiesten ja -naisten kirjeenvaihto uuden ajan alun Ruotsissa", Maarit Leskelä-Kärki, Anu Lahtinen \& Kirsi Vainio-Korhonen (toim.), Kirjeet ja historiantutkimus, Helsinki: Suomalaisen Kirjallisuuden Seura 20II, s. 85-86. 
Wirilanders definition omfattar adeln och "ofrälse personer, som höjde sig över de breda folklagren". ${ }^{9}$ Ett annat begrepp som jag använder är societet, som kan tolkas som en bredare kategori än enbart adel, samtidigt som det är en beteckning som adeln själv använde för sin samhällsgrupp. ${ }^{10}$ Bland forskare är elit en vanlig beteckning på de ståndspersoner som med hjälp av sin skriftliga och språkliga kultur, samt de sociala och kulturella normer som de odlade inom sin sfär, medvetet eftersträvade att särskilja sig från det övriga samhället. Alla ståndspersoner med någon form av ekonomisk, politisk eller social maktposition kan anses tillhöra eliten, ${ }^{11}$ men eftersom bland andra Angela Rundquist konstaterar att adeln själv undvek beteckningen ${ }^{12}$ har jag här valt att använda termerna ståndspersoner och societet.

Det är viktigt att beakta att de brevskrivare som jag studerar ingick i ett samhällsskikt som endast utgjorde en liten del av samhället. Till exempel ı8ıo räknades ungefär I6 ooo människor som ståndspersoner i Finland, ${ }^{13}$ av en total befolkningsmängd på ungefär en miljon invånare. ${ }^{14}$

\section{DÖDENS KULTURHISTORIA OCH KÄNSLOKOLLEKTIV}

Studiet av dödens historia har vuxit sedan mitten av I9oo-talet, och Philippe Ariès är en av de forskare som ofta citeras i sammanhanget. Även om Ariès i sin forskning utgick från franska förhållanden, lyfte han fram flera allmängiltiga aspekter av döden som är relevanta också för min undersökning. Han visar bland annat hur fokus i människans förhållande till döden i slutet av I7oo-talet försköts från det subjek-

9. Kaarlo Wirilander, Herrskapsfolk. Ståndspersoner i Finland I72I-I87o, övers. av Eva Stenius, Stockholm: Nordiska museet I982, s. 31.

Io. Angela Rundquist, Blått blod och liljevita händer. En etnologisk studie av aristokratiska kvinnor 1850-1900, Stockholm: Carlssons 1989, s. I3. Se även SAOB, "societet", www.svenska.se (hämtad 29/8 202I).

II. Om begreppet elit, se bland annat Topi Artukka, Tanssiva kaupunki. Turun seurapiiri sosiaalisena näyttämönä I8IO-luvulla, Helsinki: Suomen Tiedeseura 2021, s. 29-33.

I2. Rundquist, Blått blod och liljevita händer, s. I3

I3. Wirilander, Herrskapsfolk, s. II7.

I4. Seppo Koskinen et al., Suomen väestö, Helsinki: Gaudeamus 2007, s. 59 . 
tiva självet till de andra, ens närmaste, som ett resultat av ett nytt familjeideal. ${ }^{15}$

Huvudfokus i den här artikeln ligger på de känslor som döden gav upphov till hos de anhöriga, det vill säga den sorg och den tröst som uttrycktes i brev. För att kunna placera sorgen och trösten i en kontext av ritualer och traditioner till följd av dödsfall använder jag mig främst av Angela Rundquists studie av svensk adelskultur i slutet av I80o-talet, antologin Aatelin historia Suomessa där forskare redogör för adelsståndets historia i Finland och antologin Suomalaisen kuoleman historia som behandlar de olika synsätt och kulturer som omgärdat döden i Finland från järnåldern till nutid. I dag är döden i hög grad en del av det som vi klassar som privat. Så var dock inte fallet under I8oo-talet; döden samlade släkt, familj och vänner, och det hörde till att i mån av möjlighet besöka den döende för att ta ett sista farväl. Efter begravningen följde ett system av visiter och svarsvisiter. ${ }^{16}$

Det senaste decenniet har intresset för känslornas historia fått ett allt starkare uppsving; historiker har börjat värdesätta de nya infallsvinklar som känslorna kan tillföra historiska analyser och de sätt på vilka de kan stärka förståelsen för människor, samhällen, kultur och mentalitet i det förflutna. ${ }^{17}$ Enligt historikern Katie Barclay kan anläggandet av ett känslohistoriskt perspektiv belysa hur människor uttryckte, upplevde (kände) och utförde känslor i sitt dagliga liv. ${ }^{18}$

Med känslornas historia som teoretisk ram undersöker jag hur svenskspråkiga ståndspersoner i Finland uttryckte sorg, med fokus på hur uttrycken bidrog till att forma det som Barbara Rosenwein har kallat känslokollektiv (emotional community). Detta begrepp kan förklara existensen av en standard som sätter ramar för vilka känslor som är accepterade och för hur dessa ska uttryckas i olika sociala

I5. Philippe Ariès, Essais sur l'bistoire de la mort en Occident. Du Moyen âge à nos jours, Paris: Le Seuil I975, https://doi.org/IO.I4375/np.9782757850060; Philippe Ariès, L'homme devant la mort 2. La mort ensauvagée, Paris: Le Seuil I977, https://doi.org/Io.I4375/np.9782020089449.

16. Rundquist, Blått blod och liljevita händer, s. 322-33I.

17. Rob Boddice, $A$ History of Feelings, London: Reaktion Books 2019, s. 9.

I8. Katie Barclay, "The practice and ethics of the history of emotions", Katie Barclay, Sharon Crozier-De Rosa \& Peter N. Stearns (eds.), Sources for the History of Emotions. A Guide, London \& New York: Routledge 202I, s. 26, https://doi. org/Io.4324/9780429291685-3. 
grupper. ${ }^{19}$ Inom dessa känslokollektiv finns enligt Barclay gemensamma så kallade känsloregler (feeling rules) ${ }^{20}$ oskrivna regler som är så integrerade och inlärda i känslokollektivets sociala kultur att dess medlemmar i stort sett automatiskt följer dem.

Känslokollektiv är inte statiska, och olika känslokollektiv existerar parallellt i en och samma tidsperiod. Här tolkar jag kollektivet som ett inslag i societetens ambition att stärka den inre samhörigheten; känslokollektivet med dess regler var en del av gruppens sociala och kulturella norm. Rosenwein hävdar att känslor är lika viktiga som andra fenomen att beakta när man undersöker processer i det förflutna: enligt henne är känslorna och grunden till dem, liksom rådande regler för känslor och känslornas konsekvenser, omöjliga att separera från sociala processer och föreställningar om till exempel genus. ${ }^{21} \mathrm{Med}$ utgångspunkt i detta ser jag i den här artikeln känslor och uttryck för dem som en byggsten i brevskrivarnas sätt att manifestera sin tillhörighet till kollektivet.

Begreppen känslokollektiv och känsloregler är särskilt användbara när man undersöker känslor med syfte att studera individens egna upplevelser och beskrivningar av känslor, och när man försöker fånga "de vardagliga betydelserna av att känna, utföra och kommunicera känslor". ${ }^{22}$ Vilka känsloregler kan urskiljas i de brev jag undersöker och vad kan de i sin tur berätta om den känslokultur, eller det känslokollektiv, som brevskrivarna ingick i?

Att tolka de känslor som målas upp i breven utifrån den historiska kontext som de skrevs i objektivt ser jag som en utmaning, en

19. Barbara H. Rosenwein, Emotional Communities in the Middle Ages, Ithaca \& New York: Cornell University Press 2007, s. 2; se även Barclay,"The practice and ethics of the history of emotions" och Jan Plamper, The History of Emotions. An Introduction, Oxford: Oxford University Press 2015, s. 68.

20. Katie Barclay, Sharon Crozier-De Rosa \& Peter N. Stearns, "Introduction", Katie Barclay, Sharon Crozier-De Rosa \& Peter N. Stearns (eds.), Sources for the History of Emotions. A Guide, London \& New York: Routledge 202I, s. 5, https://doi.org/Io.4324/9780429291685-I.

2I. Rosenwein, Emotional Communities in the Middle Ages, s. I-5.

22. Dolores Martín-Moruno \& Beatriz Pichel,"Introduction", Dolores Martín-Moruno \& Beatriz Pichel (eds.), Emotional Bodies. The Historical Performativity of Emotions, Chicago: University of Illinois Press 2019, s. 4, https://doi.org/I0.5406/j.ctvthhcxc.5. "daily effects of feeling, doing, and communicating emotions". Översättning till svenska: E.W. 
aspekt som även Katie Barclay, Sharon Crozier-De Rosa och Peter N. Stearns lyfter fram i introduktionskapitlet till verket Sources for the History of Emotions. A Guide (202I). Utmaningen ligger i att ta reda på vad beskrivningarna av känslor betyder, då de ofta hade specifika syften, är formade av sin kontext och reflekterar skribentens motiv och intressen. Samma författare tillägger att en annan utmaning är att vi inte kan utgå från att dåtidens känslor var desamma som de är för oss i dag. ${ }^{23}$

För att hantera utmaningarna använder jag mig delvis av Monique Scheers praktikbaserade teori. Enligt henne är känslor både en upplevelse och en handling: dels har vi känslor, dels uttrycker vi dessa. Svårigheten för forskare har varit att behandla dessa aspekter av känslor som två sidor av samma fenomen, snarare än som vitt skilda fenomen. För att studera känslor i en historisk kontext menar hon att historikern måste identifiera källor som innehåller spår av analyserbara handlingar. ${ }^{24}$ Joseph Ben Prestel har konstaterat att den praktikbaserade teorin är särskilt användbar i en analys där man jämför känslor hos olika människor, ${ }^{25}$ vilket jag gör i denna artikel. Jag kombinerar Scheers perspektiv med Joanna Bourkes syn på beskrivningar av smärta $\mathrm{i}$ historisk kontext. Enligt henne är det viktigt att ta skribenten på orden när hen beskriver en känsla; om en person skriver att hen har ont eller lider bör vi acceptera det som skribentens subjektiva sanning, utan att lägga ett filter av våra egna värderingar på beskrivningen. ${ }^{26}$ Detsamma gäller för sorg; när brevskrivarna beskriver sin sorg eller det lidande som denna orsakar, har jag valt att acceptera det som en subjektiv sanning. Jag analyserar med andra ord beskrivningarna av sorg utan att psykologisera dem.

Förutom att jag beaktar det känslohistoriska teoretiska ramverket, analyserar jag de uttryck för tröst som förekommer i breven med

23. Barclay, Crozier-De Rosa \& Stearns, "Introduction", s. 3-4.

24. Monique Scheer et al., "Emotions as a kind of practice. Six case studies utilizing Monique Scheer's practice-based approach to emotions in history", Cultural History 2018:2, https://doi.org/IO.III//j.I468-2303.20I2.0062I.X.

25. Joseph Ben Prestel, "Comparative emotions", Katie Barclay, Sharon Crozier-De Rosa \& Peter N. Stearns (eds.), Sources for the History of Emotions. A Guide, London \& New York: Routledge 202I, s. I75, https://doi.org/I0.4324/9780429291685-I4.

26. Joanna Bourke, The Story of Pain. From Prayers to Painkillers, Oxford: Oxford University Press 20I4, s. 3. 
utgångspunkt i Ann-Sofie Arvidssons forskning. I artikeln "Psalmers tröst och stöd vid dödsfall” jämför hon hur trösttemat behandlas och relateras till sorgeprocessen som den framkommer i r695 och I819 års psalmböcker. Hon efterlyser studier om uttryck för tröst och sorg $\mathrm{i}$ enskilda individers subjektiva beskrivningar för att se om där finns belägg för att det var allmänt känt och spritt att psalmerna utgjorde en källa till tröst. Trösten i psalmerna var"tillgänglig för folket", dock innebär detta inte "att människor faktiskt fick hjälp via psalmerna". Särskilt i denna artikels sista avsnitt, "Tröstens känsloregler”, jämför jag hur trösttemat avspeglas i mitt källmaterial mot bakgrund av Arvidssons analys.

\section{DET RELIGIÖSA SOM KÄNSLOREGEL}

I början av I80o-talet var brevskrivandet viktigt för både män och kvinnor. Brevkonsten odlades framför allt inom samhällets högre kretsar, där den lärdes ut redan i barndomen. Breven följde en viss form och korrespondensen hade en viktig funktion för kontakten med människor på andra orter. Det förutsattes att ståndspersoner höll kontakt med andra inom samma krets och upprätthöll ett nätverk av vänner, släkt och familj. Nätverket var inte bara viktigt för att hålla kontakten - det utgjorde även ett socialt kapital och var ett centralt inslag i skapandet av den känsla av "vi" och "dem" som genomsyrade den kulturella och sociala särställning som societeten värdesatte. Breven var ett ovärdeligt verktyg i det som i forskningen har kallats för släktarbete. ${ }^{27}$

I den här kontexten får brevskrivandet en särskild betydelse, något man måste ha i åtanke under närläsningen av breven. Breven var anpassade till de rådande konventionerna och deras sanningshalt därmed ses som vinklad och anpassad; sådant som inte motsvarade

27. Johanna Ilmakunnas,"Säätyläiset ja kuolemankulttuuri I6oo-luvulta I8oo-luvulle", Ilona Pajari, Jussi Jalonen, Riikka Miettinen \& Kirsi Kanerva (toim.), Suomalaisen kuoleman historia, Helsinki: Gaudeamus 20r9, s. I36; Ijäs, "Yksilö ja yhteisö", s. 356; Kirsi Vainio-Korhonen,"Sisaruksia ja sukulaisia. Suomalaisten aatelisnaisten kirjeenvaihtoa ı60o- ja I70o-luvulla", Maarit Leskelä-Kärki, Anu Lahtinen \& Kirsi Vainio-Korhonen (toim.), Kirjeet ja historiantutkimus, s. I42; Rundquist, Blått blod och liljevita händer, s. 29. 
konventionen och omgivningens förväntningar utelämnades eller presenterades på ett sätt som ansågs accepterat.

Till släktarbetet hörde rapporter och meddelanden om sjukdom och dödsfall, i vilka de känslor som dessa frammanade hos skribenten beskrevs. Breven genomsyras av en vetskap, grundad på tidigare personliga erfarenheter, om att döden kan slå till när som helst. Framför allt är det hälsan, eller bristen på den, som oroar brevskrivarna. Detta är något som även Kai Häggman konstaterar i sin studie om familjen Wasenius på ı8oo-talet; hälsan var det viktigaste ämnet i korrespondensen, och även andra teman och frågor härleddes i en eller annan form till hälsa och sjukdom. Att ta hand om sin hälsa hörde till societetens plikter, den så kallade hälsoplikten, vilket ytterligare bidrog till det fokus som lades på hälsan. Och även om societetens sociala ställning kunde minska risken att drabbas av sjukdomar och dö i förtid, gick inte heller dess medlemmar säkra för farliga sjukdomar - döden gjorde ingen skillnad mellan rik och fattig. ${ }^{28}$ Det fokus som lades på hälsa syns i att breven ofta inleds med en fråga om mottagarens hälsa, och många gånger även avslutas med en önskan om att hen ska få förbli frisk. Till exempel Eva Sofia Crohns inleder ofta sina brev till modern Ulrika Möller med formuleringen "skyndar mig att säga Min Goda Mamma det vi alla Gud vare låf! må väl!”, ${ }^{29}$ och avslutar med hälsningar som "[j]ag sluter med de varmaste önskningar för min högvördade Mammas fortfarande helsa" ${ }^{30}$. Liknande uttryck finns bland annat i Selma Augusta Europaeus brev till sin mamma Lovisa Constance Lampa, och den största oron tycks ha handlat om att mamman kunde ha blivit sjuk:

$\mathrm{Nu}$ har jag åter varit 3 poster utan bref, jag vet ej huru jag denna post så säkert trodde mig få; men fick ej; måtte min egen, så älskade Mamma blott vara frisk, skulle jag endast säkert veta det, så vore det ej så ledsamt, ty jag finner ju att Mamma nu har så många att skrifva till; men den fruktan är så svår. ${ }^{31}$

28. Häggman, Perheen vuosisata, s. 70-75.

29. E.S. Crohns till U. Möller, $29 / 4$ I82I, Samuel Möllers arkiv, RA.

30. E.S. Crohns till U. Möller, $24 / 2$ I82ı, Samuel Möllers arkiv, RA.

3I. S.A. Europaeus till L.C. Lampa, 8/12 I851, Europaeus släktarkiv, RA. 
Av källorna kan man utläsa en ständig osäkerhet inför morgondagen. Stora avstånd mellan skribenterna ökade oron, och breven ger ett intryck av att människorna aldrig kände sig säkra på att mottagaren var frisk - i praktiken uttryckte man alltså en rädsla för att hen kunde vara döende. Samtidigt kan man i sammanhanget skönja den struktur som lärdes ut i brevskrivandet och i vilken frågor om hälsa var ett självklart inslag. Detta blir särskilt tydligt som önskningarna och frågorna om hälsa återkommer i alla brev, oberoende av mottagare, ålder eller skribenternas relation. Men strukturen fanns också där av en orsak - vetskapen om att den andras hälsa snabbt kunde försämras.

Med tanke på de dödsfall som medlemmarna i alla familjerna hade upplevt - i sin egen krets och även i periferin av sin umgängeskrets - saknade oron inte grund. I en stor del av breven nämns någon på orten som antingen är sjuk eller har dött. I korta bisatser beskrivs dödsfall och bekymmer för de anhöriga, och ibland också i längre berättelser, som i Selma Augusta Europaeus brev till sin mamma den 6 januari 1852 :

Hvad den goda Lagmanskans död mycket kostade uppå mig; så vandrar den ena efter den andra af våra bekanta och vänner, och vi veta så litet när vår egen stund är kommen. $\mathrm{O}$, måtte man alltid vara beredd, ty offta kallar Gud en så hastigt att man ej hinner sända till Honom ens en enda suck. ${ }^{32}$

Efter detta ger hon ett exempel på hur snabbt döden kunde inträffa när hon berättar om sin granne Carolina Hjerppe som ”dog i fredags inom mindre än ett ögonblick, hon var alldeles frisk, och satt just och talade med främmande som der var, och föll med detsamma stendöd ned för deras fötter, utan det minsta ljud". ${ }^{33}$ Under en stor del av den tid från vilken det finns bevarade brev var Selma Augusta Europaeus själv sjuk och hon dog våren 1852 . Hon uttrycker ingen rädsla för sin egen död utan oron gäller alltid de närstående, främst barnen och maken. Hon sörjer andras död och oroar sig över hur det ska gå för dem som blir kvar om hon själv dör.

32. S.A. Europaeus till L.C. Lampa, 6/I I852, Europaeus släktarkiv, RA.

33. Ibid. 
I det här sammanhanget kan man knyta an till Ariès undersökning av döden, där han slår fast att fokus i slutet av I70o-talet försköts från rädsla för den egna döden till oro för den andras död. Denna förskjutning syns särskilt i korrespondensen mellan Selma Augusta Europaeus och hennes mor, där oron för den andras eventuella död ständigt återkommer. Samtidigt kan detta, att bortse från sig själv och i stället lägga fokus på de närstående, handla om en annan, kulturell aspekt. Historikern Yvonne Maria Werner lyfter i en artikel om ars moriendi (konsten att dö) fram de religiösa förväntningar som fanns på människorna - att leva rättfärdigt för att kunna ta emot frälsningen vid döden - och hävdar att det funnits en förväntning både i den katolska och lutheranska tron på "den döende att aktivt medverka i dödsberedelsen och utan bitterhet och rädsla förtröstansfullt överlåta sig i Guds händer" ${ }^{34}$ Det är också viktigt att komma ihåg det praktiska som säkerligen låg till grund för människornas oro för sina närstående: dödsfall inom familjen fick stora följder för de efterlevande. En fars död kunde innebära stora ekonomiska svårigheter, medan en mors död ofta innebar en omformering av familjen om fadern gifte om sig. ${ }^{35}$

Selma Augusta Europaeus uttrycker i sina brev en tro på att Gud håller hennes liv i sina händer. Här kan troligen också hennes ställning som prästfru ha spelat en roll. Ett par månader innan hon dog, när hon hade varit svårt sjuk och dessutom var höggravid, skrev hon bland annat:"väl skulle jag också ännu gerna lefva, då jag har en så obeskrifligt god Man [...] samt så många små Barn", och tillade"men ser Mamma, är det så Guds beslut att kalla mig, så dör jag äfven lika gerna." Hon uttryckte förvissning om att barnen skulle vara i goda händer om hon dog, eftersom "Gud på ett osynligt sätt drager försorg om de små”. ${ }^{36}$ Selma Augusta Europaeus fann med andra ord tröst i försynen och gav uttryck för att hon varken oroade sig för sig själv eller barnen.

Av de brevskrivare som jag studerat är Lovisa Constance Lampa den som starkast uttrycker sin oro för den andra, i det här fallet sin dotter. När Selma Augusta Europaeus hälsa blev sämre uppmanade

34. Yvonne Maria Werner,"Ars moriendi i kampen om det'goda' samhället", Yvonne Maria Werner (red.), Döden som katharsis. Nordiska perspektiv på dödens kultur-och mentalitetshistoria, Lund: Almqvist \& Wiksell 2004, s. I49.

35. Ijäs, "Yksilö ja yhteisö", s. 352-355.

36. S.A. Europaeus till L.C. Lampa, $19 / 3$ I852, Europaeus släktarkiv, RA. 
modern henne gång på gång att komma till Helsingfors för att söka vård. Med tiden kan man skönja en växande uppgivenhet inför dotterns lugna inställning till sin allt sämre hälsa, som i följande citat från ett brev daterat den 5 mars 1852 :

Men söta Selma, låt ej ändå tålamodet öfvergifva dig, hoppas allt af Den präktige som skickar sjukdomen, att Han äfven kan om det är Hans vilja, återgifva hälsan, änu äger jag ett hopp om en förtröstan härom. ${ }^{37}$

Därefter vänder sig Lampa direkt till Gud med en bön, och framför ett önskemål till dottern om att "änu en gong här på jorden få sluta dig mitt goda värderade barn i min famn”. Hon uttrycker med andra ord både en religiös förtröstan och oro för den andra. Samtidigt kan man här skönja den paradox som också fanns inbyggd i de regler som dels den döende, dels de anhöriga förväntades följa. Som god medmänniska förväntades man bry sig om och trösta den andra, men samtidigt måste man vara medveten om att man inte kunde trösta; tröst fanns när allt kom omkring bara i det gudomliga. En bristande förtröstan på detta kunde skada både en själv och den andra, och det var därför viktigt att ha en stark tilltro till försynen. ${ }^{38}$

Selma Augusta Europaeus lugn kan ses som ett uttryck dels för att hon förlikade sig med vad som förväntades av henne som god prästfru, dels för att hon inte ville oroa sin mamma. I moderns brev till dottern syns samtidigt en kamp mellan det förväntade - det rätta - och det som hon kanske verkligen kände. Hon uttrycker inte samma fullständiga tilltro till Guds vilja, tron fråntar inte henne de mänskliga känslorna och hon oroar sig mycket, samtidigt som hon ändå försöker påminna sig själv och dottern om försynens allmakt.

Den religiösa tilltron blir synlig hos alla de personer vars brev jag analyserat. Den uttrycks i böner till Gud om att han ska skydda de närstående och syns också i tron på att försynen styr och att människan

37. L.C. Lampa till S.A. Europaeus, 5/3 I852, Europaeus släktarkiv, RA.

38. Ann-Sofie Arvidsson,"Psalmers tröst och stöd vid dödsfall”, Yvonne Maria Werner (red.), Döden som katharsis. Nordiska perspektiv på dödens kultur- och mentalitetshistoria, Lund: Almqvist \& Wiksell 2004, s. I39. 
behöver lita på att det är bäst så. Som Anna Maria Ehrström skrev till dottern Gustava Ehrström, några månader efter pappans död I835:

[...] hans bortgong begråte vi ännu, ty han var för dyrbar för alla, men Försynens förundransvärda skickelse bestämde vår skiljsmessa och hans skickelser med sine uti denna vansklighetens verld vandrande barn är ju det bästa om och så profvet är bittert. ${ }^{39}$

Den religiösa tilltron syns också i den lugna inställning brevskrivarna uttrycker i förhållande till sin egen död. Det religiösa är på så sätt närvarande i alla aspekter av döden, vilket är förenligt med de förväntningar på ars moriendi och ars vivendi (det rätta sättet att leva) som fanns och de uppmaningar som tidens psalmer gav; man skulle finna tröst i det gudomliga, genom böner och tro. ${ }^{40}$

Även Samuel Fredrik von Born nämner Guds vilja då han skriver om döden. Några dagar innan hans fru dog skrev han bland annat att hustruns liv var beroende av "Guds nåd". ${ }^{41}$ I brev till Eva Mathilda Aminoff uttryckte sig bland andra hennes syster, mor och väninnor om försynen i samma bemärkelse. ${ }^{42}$ Eva Mathilda Aminoffs bror, Gustaf Adolf Bruncrona, skrev i liknande ordalag den 22 februari I808, när Johan Fredrik Aminoff var allvarligt sjuk: "Han [Johan Fredrik] går sitt öde till mötes. Vi kunna ej rubba dess lagar. Vill Försynen som jag hoppas rädda honom, så sker det utan att vi knota." ${ }^{43}$ Bruncrona ger uttryck för den underkastelse som konventionen förespråkade och uppmanade sin syster att göra detsamma - utan att vare sig sörja eller beklaga försynens beslut, vilket det än var. Ulla Ijäs konstaterar att gudstron för de finländska ståndspersonerna var en "naturlig del av livet, och trosfrågor diskuterades inte nödvändigtvis särskilt djupt". ${ }^{44}$ Detta framgår upprepade gånger av de brev som jag har analyserat, och

39. A.M. Ehrström till G. Ehrström, I6/9 I835, Borenius släktarkiv, RA.

40. Arvidsson, "Psalmers tröst och stöd vid dödsfall", s. I26-I27.

4I. S.F. von Born till C.F. von Born, I2/ıo I835, Äldre Sarvlaks arkiv, SLSA.

42. E.M. Bruncrona till E.M. Aminoff, $29 / \mathrm{I}$ I8I9 och M.J. Bruncrona till E.M. Aminoff, 6/4 I8I5, Rilax samling, RA.

43. G.A. Bruncrona till E.M. Aminoff, 22/2 I808, Rilax samling, RA.

44. Ijäs, "Yksilö ja yhteisö", s. 36o. "[...] luonnollinen osa elämää, eikä uskonnollisia kysymyksiä välttämättä pohdittu kovinkaan syvällisesti.” Översättning till svenska: E.W. 
det faktum att trosfrågorna sällan diskuteras utan uppfattas som en självklarhet gör att det religiösa kan ses som en del av de känsloregler som societeten följde. Samtidigt blir det tydligt att religionen var en enande komponent och en central byggsten i det känslokollektiv som kretsen utgjorde.

\section{SPRÅKET SOM FÖRENANDE FAKTOR I KÄNSLOKOLLEKTIVET}

Dödsfall har i alla tider och i hela världen omgärdats av ritualer och regler som har fungerat som verktyg för människan att förklara och acceptera döden. ${ }^{45}$ Direkt efter döden skulle bland annat den dödas kropp tvättas och förberedas för graven, och man behövde beställa kistan, köpa svartkantat brevpapper och svart brevlack, beställa och skicka sorgebrev samt sy eller ställa i ordning sorgdräkterna. ${ }^{46}$ Rundquist konstaterar att döden och de ritualer som var förbundna med den, precis som högtider, var tillfällen där societeten agerade "som en stor familj”. Döden var en angelägenhet som inte angick bara de närmaste, och framför allt familjens kvinnor hjälptes åt i förberedelsen av liket. De regler och traditioner som följde med ett dödsfall var viktiga att följa. ${ }^{47}$ Samuel von Born skrev till sina söner och bad dem redan under resan hem från sin grand tour ordna med sina "sorgsaker, pugnetter, långhalsduk, hals krage med breda fållar" när deras mor Catarina Elisabet von Born hade dött. ${ }^{48}$ Detta kunde inte vänta tills sönerna kom hem, vilket visar att de yttre tecknen på sorg tillskrevs betydelse.

Att analysera de ritualer och handlingar som nämns i källmaterialet är ett viktigt komplement till studiet av känslor, eftersom konventionerna avspeglar den allmänna värdegrunden och synen på livets olika skeden. De kan också ses som exempel på de "spår av analyserbara handlingar" som Monique Scheer nämner som viktiga i studiet av känslor. Ritualerna är direkt kopplade till känslorna, vil-

45. Kaarina Koski \& Ulla Moilanen, "Kuolema ja tuonpuoleinen", Ilona Pajari, Jussi Jalonen, Riikka Miettinen \& Kirsi Kanerva (toim.), Suomalaisen kuoleman historia, Helsinki: Gaudeamus 20I9, s. 6I-64.

46. Ilmakunnas, "Säätyläiset ja kuolemankulttuuri i6oo-luvulta I8oo-luvulle", s. I36.

47. Rundquist, Blått blod och liljevita bänder, s. 323-33r.

48. S.F. von Born till C.F. och J.A. von Born, $27 /$ Io I835, Äldre Sarvlaks arkiv, SLSA, understrykningar i originalet. 
ket även historikern Inga Floto konstaterar: "Ritualer kan definieras som en form av kommunikation, som genom symboler direkt återger känslor." ${ }^{49}$ Samtidigt är det viktigt att komma ihåg att det fanns ett förväntat mönster att följa; reglerna kring sorgeprocesser och dödsfall var länge starka. Scheer betonar att ritualerna inte bör betraktas som något som direkt åtföljs av känslor, utan att de också kan ses som ett sätt att utöva känslor på. Ritualerna omvandlar således känslor till praktiker (emotional practices). ${ }^{50}$

Friherre Carl Fredrik Rotkirch (I775-I832) beskriver i brev till senator Gustaf von Kothen (I778-I85I) de ritualer som omgärdade hans fars, major Wentzel Fredric Rotkirchs död den 30 januari I8I4. När fadern dog efter några dagars sjukdom "uplöstes själ och kropp och återstod för oss alla största sorg och bedröfvelse". Rotkirch skriver om begravningen, som skulle ordnas i Borgå domkyrka med femtio inbjudna gäster, varefter faderns lik skulle föras till familjegraven "utom staden ett litet stycke". Han skriver också om bestyret med att skaffa fram sorgdräkterna för familjen. Hans äldsta son Johan, eller Janne, bodde vid den här tiden hos senator von Kothen, och Rotkirch ber i brevet till von Kothen att han ska"utrusta Janne i tilbörlig sorgdrägt". Även sorgebreven skulle beställas och tryckas; Rotkirch hade beställt I20, men konstaterar att det inte räckte och att han gång på gång kom ihåg personer som han glömt. Så skedde bland annat medan han skrev brevet till von Kothen. ${ }^{51}$

Dessa ritualer och konventioner i samband med dödsfallet förefaller ha gett Rotkirch en distraktion i sorgen. Dock framgår det att ritualerna var en sak, medan sorgen fanns kvar ännu efter att det formella och officiella var avklarat: "I I4 dagar skall efter bruket

49. Inga Floto, "Døden i historien - historiografiske perspektiver", Yvonne Maria Werner (red.), Döden som katharsis. Nordiska perspektiv på dödens kultur- och mentalitetshistoria, Lund: Almqvist \&Wiksell 2004, s. 32."Ritualer kan defineres som en form for kommunikation, der meddeler sig direkte til følelserne gennem symboler." Översättning till svenska: E.W.

50. Yvonne Maria Werner,"Inledning", Yvonne Maria Werner (red.), Döden som katharsis. Nordiska perspektiv på dödens kultur- och mentalitetshistoria, Lund: Almqvist \& Wiksell 2004, s. 7. Monique Scheer, "Are emotions a kind of practice (And is that what makes them have a history)? A bourdieuian approach to understanding emotion", History and Theory 5I, 2012:2, s. 194 .

5I. C.F. Rotkirch till G. von Kothen, 3/2 I8I4 och Io/2 I8I4, von Kothens släktarkiv, RA. 
förmaket ännu vara hvitklädt som ökar dysterheten hos mig med tillägg af de svartklädda små ungarne”, skrev han två dagar efter begravningen, och tillade att han veckan därpå tänkte resa bort för att "litet distrahera" sig. ${ }^{52}$ Det blir tydligt att en närståendes död inte bara handlade om känslor, utan i hög grad också om praktiska arrangemang. Dessa följde en strikt struktur som inte bara handlade om de yttre uttryck som talade om för andra att man bar sorg, utan även om sociala förväntningar och plikter.

I början av I80o-talet ansågs det även berättigat att oroa sig för framför allt de fruar som riskerade förlora sin make eller de barn som riskerade förlora sin pappa. En intressant förskjutning som Arvidsson noterar är att det i 1695 års psalmbok inte läggs någon vikt vid den sorg som en mors eller hustrus död orsakade en familj. Makens och faderns död innebar ofta större ekonomiska svårigheter för de efterlevande än hustruns eller moderns död, och det var bara vid en makes eller faders död som tröst ansågs behövas. I I8r9 års psalmbok beaktas däremot även makans, moderns och barnens död, vilket kan tolkas som att man har börjat lägga större vikt vid det känslomässiga, snarare än enbart det praktiska. ${ }^{53}$ Detta har säkert också en koppling till hur synen på familjen förändrades i slutet av r7oo-talet och under början av I8oo-talet. Jean-Jacques Rousseau och andra upplysningsfilosofer började bland annat fästa vikt vid moderskärleken. Vid den här tiden uppstod i delar av Europa det som Élisabeth Badinter har benämnt "den nya familjen", som bildade en ny privat sfär och gjorde den självuppoffrande kärleksfulla modern till ett ideal. ${ }^{54}$

Oron för det praktiska syns även i brevmaterialet, bland annat i ett brev från Gustaf Adolf Bruncrona till systern Eva Mathilda Aminoff, skrivet när Eva Mathildas man Johan Fredrik Aminoff var sjuk:

De billiga [rimliga], de rörande känslor du deri [i brevet] yttrar hafva kostat mig heta tårar, och när runno de med mera skäl? Föreställningen af en maka omgifven af späda barn [...] föreställningen af

52. C.F. Rotkirch till G. von Kothen, ro/2 I8I4, von Kothens släktarkiv, RA.

53. Arvidsson, "Psalmers tröst och stöd vid dödsfall", s. I3I, I35.

54. Élisabeth Badinter, Den kärleksfulla modern, Stockholm: Gidlund I98I, s. II2-II9, I42, I53-I56; Philippe Ariès, L'enfant et la vie familiale sous l'ancien régime, Paris: Plon i96o, s. 465 . 
en olyklig framtid för en fattig värnlös famille [...] måste såra ett känslofullt hjerta. ${ }^{55}$

Eva Mathilda Aminoffs brev, som brodern här svarar på, finns inte bevarat, men hans svar tyder på att hon hade oroat sig inför framtiden då risken fanns att maken skulle dö av den sjukdom han led av, men som han senare tillfrisknade från. Enligt brodern var hennes farhågor inte heller ogrundade. Värt att notera är att han inte tröstar henne, utan snarare spär på hennes oro genom att måla upp föreställningar om "en fattig värnlös famille" - utan att erbjuda någon hjälp utifall att det värsta skulle inträffa.

Det sociala nätverk som upprätthölls genom släktarbetet var av särskilt stor vikt i de fall då maken dog och efterlämnade hustru och barn. Den hustru som då saknade både släkt och ett nätverk av vänner hade det svårt. Detta framgår också av Selma Augusta Europaeus och Lovisa Constance Lampas brev, där de upprepade gånger diskuterar sin gemensamma väninna Aurora Boldt. Aurora hade flera små barn och förlorade uppenbarligen sin ekonomiska säkerhet när maken dog. Hon tycks ha saknat släktingar och därför försökte både Selma Augusta och Lovisa Constance hjälpa henne så gott de kunde, vilket också förväntades inom societeten som präglades av en stark solidaritet. ${ }^{56}$

I denna kontext förstår man hur viktigt det tidigare nämnda släktarbetet var och varför kvinnorna ansträngde sig som de gjorde för att upprätthålla sina sociala nätverk; de var inte bara ett sätt att trygga den sociala positionen, utan handlade också om att skaffa sig en försäkring för sig själv och familjen för den eventualitet att maken dog. ${ }^{57}$

Sorgen över döda barn - både egna och andras - nämns i många brev. I de flesta fall beskrivs dödsfallen med starka känslouttryck, både av föräldrarna och i kondoleansbrev av andra anhöriga. Till exempel Carl Fredrik Rotkirch skrev om sin yngsta dotter som hade dött som spädbarn: "Det lilla söta älskvärda barnet Natalie är ej mer. Hon ligger kall utanför Mammas sängkammare, ännu änglalik och

55. G.A. Bruncrona till E.M. Aminoff, 22/2 1808, Rilax samling, RA.

56. Ijäs, "Yksilö ja yhteisö", s. 362-363; Rundquist, Blått blod och liljevita bänder, s. $284-287$.

57. Se mer i Knipström, "Hvad är livet då hälsan saknas?", särskilt kapitel 2, avsnitt I och kapitel 3 . 
skall det och förblifva i sitt förklarade tilstånd." 58 Även Johan Fredrik Aminoff uttryckte sig med liknande ord när två av hans döttrar hade dött i februari 1815:

minnet af Edra Engla bilder, Edra späda hjertan lika goda som menlösa och glada, lofvande, hoppfulle, sväfvar för min inbildning evigt - evigt [...] och våra tårar, förälldrars tårar fugta Eder aska så länge vi mägta dem utgjuta. ${ }^{59}$

Dessa närmast poetiska uttryck sticker ut i materialet för en läsare i modern tid. Språket och det sätt på vilket man formulerade sig var en byggsten i känslokollektivet: i upprätthållandet av en känsla av "vi" och "dem". Språket var en viktig klassmarkör och det fanns därmed förväntningar på hur man skulle uttrycka sig. ${ }^{60}$ Samma typ av bilder och uttryck återkommer i flera av breven, i olika familjer; på samma sätt som ritualerna kan ses som en modell för de sörjande, kan brevskrivandets formmässiga konventioner hjälpa skribenterna att hitta "de rätta orden". Det hörde till utbildningen att lära sig det rätta sättet att uttrycka sig i brev, men det fanns en skillnad i uttryckssätt mellan fäder och mödrar. Fäderna hade sedan ung ålder blivit skolade till goda brevskrivare, ofta på flera språk, medan kvinnornas utbildning var betydligt mer sparsam och de därför länge uttryckte sig mer anspråkslöst än männen. ${ }^{61}$

Exempel på mer sakliga beskrivningar av döden hittas ofta i brev skrivna av kvinnor. Till exempel Eva Sofia Crohns brev till modern Ulrika Möller, där hon beskriver sonens död, ter sig nedtonat i jämförelse med greve Aminoffs och friherre Rotkirchs beskrivningar ovan:

58. C.F. Rotkirch till G. von Kothen, 23/1o I819, von Kothens släktarkiv, RA.

59. J.F. Aminoff till G. von Kothen, $2 \mathrm{I} / 2 \mathrm{I} 8 \mathrm{I5}$, von Kothens släktarkiv, RA.

6o. Rundquist, Blätt blod och liljevita händer, s. 36 .

6r. Maarit Leskelä-Kärki, Anu Lahtinen \& Kirsi Vainio-Korhonen (toim.), Kirjeet ja historiantutkimus, Helsinki: Suomalaisen Kirjallisuuden Seura 20II, framför allt följande kapitel: Anu Lahtinen, Maarit Leskelä-Kärki, Kirsi Vainio-Korhonen \& Kaisa Vehkalahti,"Kirjeiden uusi tuleminen" och Kaisa Vehkalahti,"Opitut tunteet, kerronnan kaavat". 
$\mathrm{Nu}$ hafva Vi en vecka varit boende på Landet, som redan iklädt sig Sommarens förtjusande drägt; men likväl har denna första vistelse här ej för oss varit angenäm; ty par dagar efter vår utflyttning sjuknade vår Lille Gosse [Nestor]: och oagtadt ingenting sparades eller blef försummadt af Doctor Melart, som var hans Läkare, slutade han sin korta vandring här efter fyra dagars sjukdom: Doctorn kallade denna sjukdom nerfslag på hjernan, för hvillket han säger att de flesta Själfulla, och lifliga Barn äro vid det tredje året utsatte: vi kunna således icke förebrå oss någon origtig behandling med honom, då denna sjukdom härrörde af et natur-anlag; men i alla fall är denna förlust grufligt påkåstande, hvillket Mammas ömma hjerta lätt föreställer sig, som sjelf försökt dylika förluster: I går på Pingst dagen blef vår Lille Älskling begrafven. ${ }^{62}$

Från början av I70o-talet blev det framför allt bland adeln vanligt att eftersträva ett "spontant språk som påminde om talspråk, med hjälp av en skrivstil som var fylld av känslouttryck". ${ }^{63}$ Vad bristen på starka känslouttryck i Eva Sofias brev berodde på är svårt att säga i efterhand, det kan också ha handlat om hennes personlighet eller hennes relation till sin mamma. Samtidigt odlades i många familjer en särskild brevkultur, med ett specifikt språkligt ideal som gick i arv från en generation till en annan och därmed färgade familjemedlemmarnas sätt att uttrycka känslor. ${ }^{64}$ Ett mindre rikt brevspråk behövde därför inte tyda på svagare känslor; snarare handlade det om en skillnad i kultur och konventioner inom olika familjesfärer, det vill säga varierande känsloregler i olika känslokollektiv. Känsloreglerna behövde inte förklaras eller tydliggöras inom respektive kollektiv, utan alla dess medlemmar kände till och förstod vad som förväntades av dem när det gällde att förmedla känslor.

Societeten, liksom ståndssamhället som helhet, präglades också av en tydlig patriarkal hierarki där var och en visste sin plats. ${ }^{65} \mathrm{Hie}-$ rarkin existerade även inom familjerna vilket betyder att skrivsättet

62. E.S. Crohns till U. Möller, 7/6 I827, Samuel Möllers arkiv, RA.

63. Lahtinen, Leskelä-Kärki, Vainio-Korhonen \& Vehkalahti,"Kirjeiden uusi tuleminen", s. I6. "spontaanin, puhuttua kieltä muistuttavan, tunteikkaan kirjoitustyylin avulla." Översättning till svenska: E.W.

64. Ilmakunnas, "Säätyläiset ja kuolemankulttuuri r6oo-luvulta ı80o-luvulle", s. 137-I38. 65. Ijäs, "Yksilö ja yhteisö", s. 362 . 
och formuleringarna ytterligare påverkades av vem som skrev till vem. Styrkan i känslouttrycken kan därför också påverkas av skribentens relation till brevets mottagare. Ett exempel på detta hittas i friherrinnan Augusta Fredrika Elisabet Rotkirchs brev till sin makes morbrors fru, grevinnan Eva Mathilda Aminoff. Här finns både en hierarkisk skillnad, där friherrinnan stod under grevinnan i adelshierarkin, och en generationsskillnad; de två kvinnorna var jämngamla men Eva Mathilda Aminoff var gift med friherrinnan Rotkirchs makes morbror. Den 3 juli I82I skrev friherrinnan Rotkirch och beklagade grevinnan Aminoffs förlust av sin endast en månad gamla dotter:

[...] förlussten af den Lilla Dottern har säkert kåstatt på Fasters hjerta ehuru dess bekantskap ännu hvar ändast ganska ny, men bättre ändå att förlora dem som så små än då de hunnit fässta oss med starkare band igenom dett dagliga umgänget. ${ }^{66}$

Skillnaden är märkbar när man jämför citatet med de brev som Eva Mathilda Aminoff fick av sin bror Gustaf Adolf Bruncrona, där känslorna uttrycktes med starka ord som till exempel:"De billiga [rimliga], de rörande känslor du deri [i brevet] yttrar hafva kostat mig heta tårar.” ${ }^{67}$ Uttryckssättet skiljer sig också från det sätt på vilket Samuel Fredrik von Born skrev till sina söner, till exempel när han meddelade dem att deras mor hade dött: ”Ack! bloden vill stelna i mina ådror då jag nödgas utsäga det fasansfulla ordet, att Eder så Högt Älskade, Hulda Mamma icke mera finnes ibland oss på jorden.”68

Det är troligt att hierarkin inom societeten, åtminstone i vissa fall, hade en stark inverkan på skribenternas respektive känslokollektiv. Olika skribenter ingick parallellt i en mängd känslokollektiv som påverkades av ålder, rang och personliga relationer inom familjer, släkter och bekantskapskretsar.

66. A.F.E. Rotkirch till E.M. Aminoff, $3 / 7$ I821, Rilax samling, RA.

67. G.A. Bruncrona till E.M. Aminoff, 22/2 I808, Rilax samling, RA.

68. S.F. von Born till C.F. och J.A. von Born, 23/ro 1835, Äldre Sarvlaks arkiv, SLSA. 
Att höra till societeten medförde även starka traditioner, förväntningar och en klasskänsla, som enligt Rundquist var inlärd och genom vilken "individerna gjorde anspråk på att besitta en medfödd och nedärvd värdighet”. ${ }^{69}$ Som redan framgått var särskilda språkliga uttryckssätt och släktarbetet en del av de förväntningar som ställdes på medlemmarna i kollektivet och ordvalen i breven formade sig efter dessa. Enligt Ulla Ijäs smälte "yttre meriter, inre egenskaper och ett inlärt beteende" framför allt hos adeln samman i en "harmonisk helhet". ${ }^{70}$

I sin analys av psalmer konstaterar Arvidsson att den känslosamma sorgen framträder tydligare i I8I9 års psalmbok än i psalmboksutgåvan från I695. ${ }^{71}$ Detta är något som även avspeglas i I80o-talets brevideal; känslorna beskrivs mångordigt och med starka uttryck. Paradoxalt nog hörde detta till brevens stil, samtidigt som de som tillhörde societeten förväntades kunna behärska sina känslor. ${ }^{72}$ Ett exempel på brevens ymniga känslouttryck representerar följande citat:

O Gud! mitt hjerta är förkrossat åk jag söndersliter Edert! O Gud!!! [...]. Min Sophie!! ... ack min lilla Eva min[a] älskade barn är icke mer!!! Döden, den grymma döden har för dem afklipt lefnads tråden [...] och hoppet försvunnit att se deras älskade händer tillsluta mina igen! O Gud! tröste min maka! jag kan ej göra det. Sorgen öfverväldigar min egen känslofulla själ. ${ }^{73}$

Så här skrev Johan Fredrik Aminoff till sin vän Gustaf von Kothen dagen efter att två av hans döttrar dött: den I9 och den 20 februari I8I5. Ytterligare en dotter skulle dö strax därefter. Redan under I7oo-talet fick breven en alltmer förtrolig ton; man försökte skriva på ett sätt som fick avståndet till mottagaren att kännas mindre och som skulle

69. Rundquist, Blått blod och liljevita händer, s. 29.

70. Ijäs, "Yksilö ja yhteisö", s. 362." [...] ulkoiset avut, sisäiset ominaisuudet ja opittu käytös sulautuivat harmoniseksi kokonaisuudeksi." Översättning till svenska: E.W.

71. Arvidsson, "Psalmers tröst och stöd vid dödsfall", s. I3I-I35.

72. Ijäs, "Yksilö ja yhteisö", s. 363 .

73. J.F. Aminoff till G. von Kothen, 2I/2 I8I5, von Kothens släktarkiv, RA. 
påminna om en vanlig konversation. ${ }^{74}$ Det är tänkbart att de starka känslouttrycken också behövdes för att nå fram genom brevpappret och framkalla samma känslor hos mottagaren. På så sätt stärktes upplevelsen av en delad erfarenhet.

Dessa starka uttryck syns tydligast hos Johan Fredrik Aminoff, som var född i mitten av I7oo-talet och därmed säkert påverkad av I70o-talets manliga ideal. Enligt detta skulle en man vara "stolt och självständig", och därtill "en kultiverad hovman" som var bevandrad i retoriken och hade "förmågan att behaga och konversera" ${ }^{75}$ Dessa förmågor behövde också föras fram, vilket avspeglas i till exempel greve Aminoffs brev till sin vän och jämbördige, von Kothen. Aminoff brevväxlade med von Kothen under större delen av sitt liv, och även om von Kothens svar till honom har bevarats endast i liten utsträckning kan man anta att det under årens lopp byggdes upp specifika förväntningar dem emellan, ett slags avtal om känsloregler. Sådana avtal gällande uttryckssätt och de känslor som accepterades etablerades sannolikt, på olika sätt, mellan varje par av brevskrivare.

Förväntningarna på att man skulle behärska sina känslor syns däremot i Eva Sofia Crohns brev. När friherrinnan von Knorrings dotter dog 1822, uttryckte Eva Sofia Crohns sin oro för väninnan:

\begin{abstract}
Allt sedan [flickans död] hafva vi tre hushåll nästan dageligen varit tillsammans för att så mycket, som möjligt skingra Friherrinnan Knorrings oro, som i dess nuvarande belägenhet är henne ganska skadlig. [...] Grufligt smärtande vore det för mig att förlora min lilla Torsten; men jag bereder mig småningom därpå, för att med mera förnuft och undergifvenhet underkasta mig Guds villja. ${ }^{76}$
\end{abstract}

Av det här citatet framgår inte bara en förväntning på att kunna behärska sina känslor, utan också en av orsakerna till att man uppmuntrades att sörja "med förnuft och undergifvenhet"77. Man trodde

74. Vainio-Korhonen, "Sisaruksia ja sukulaisia", s. I4I.

75. Johanna Ilmakunnas, Ett ståndsmässigt liv. Familjen von Fersens livsstil på I7oo-talet, övers. Camilla Frostell, Helsingfors: Svenska litteratursällskapet i Finland \& Stockholm: Atlantis 2012, s. I30.

76. E.S. Crohns till U. Möller, 23/3 I822, Samuel Möllers arkiv, RA.

77. Ibid. 
nämligen att överdriven sorg kunde leda till mjältsjuka ${ }^{78}$ - ett annat ord för melankoli, en av I700- och I80o-talens kultursjukdomar ${ }^{79}-$ som ansågs kunna leda till självmord. ${ }^{80}$

Johan Fredrik Aminoff oroade sig också för sin hustrus sorg efter barnens död, trots att han även själv utgöt starka känslor i sina brev dagarna efter deras bortgång. Troligen avspeglas här en balansgång som handlade om hur länge man fick sörja kraftigt för att det inte skulle vara skadligt. Av ett brev från Aminoff till hustrun framgår det nämligen att hon drygt två månader efter de tre döttrarnas död fortfarande sörjde djupt:

Låtom oss gråta min vän det är våra hjertans utgjutande, hugsvalelse och tröst. Gud hade gifvit oss dessa Englar i menniskogestalt värdige att saknas och begråtas. De äro då ej mer!!! Men deras minne vara i våra hjertan så länge de mäkta att klappa i tiden; men låtom oss sörga min vän, på ett sätt värdigt vårt upphof och oss sielfva, framför alt ej orättvisa våra lika, ty den barbar är icke född som uppsåtligt velat frånrycka oss våra barn, och ännu torde icke ett allmännare deltagande ägt rum i förälldars djupa sorg, än den vi skörda $\left[\ldots .{ }^{81}\right.$

Här antar Aminoff rollen som den faderliga och mer förnuftiga maken, som råder sin hustru att sörja på ett sätt "värdigt vårt upphof och oss sielfva". Man kan ana att han upplever att hon sörjer mer än vad som är passande, eller kanske hälsosamt. Hon bryter mot känsloreglerna som här hänger samman med en grundläggande norm inom den adliga kultursfären: att man bör uppträda på det sätt som är rätt för

78. Detta nämns bland annat i brevet från E.M. och E.C. Bruncrona till E.M. Aminoff 29/I I8I9, Rilax samling, RA. För mer om melankoli, se bland annat Karin Johannisson, Melankoliska rum. Om ångest, leda och sårbarhet i förfluten tid och nutid, Stockholm: Bonnier 2009 .

79. Kultursjukdomar är en benämning på tillstånd som i en viss kultur eller tid har betraktats som en sjukdom. Dessa sjukdomar färgar sin tids medicinska diskurs och speglar den kultur de existerar inom. Se mer i bland annat Karin Johannisson, Den mörka kontinenten. Kvinnan, medicinen och fin-de-siècle, Stockholm: Norstedts 2013 [1994].

8o. Johannisson, Medicinens öga, s. IOI-IO4.

8I. J.F. Aminoff till E.M. Aminoff, 23/5 I815, Rilax samling, RA. 
ens eget stånd. ${ }^{82}$ Arvidsson hittar också belägg för en sådan syn i sin analys och menar att det var tillåtet att sakna den avlidna och att den dödas heder i viss utsträckning krävde sorg, samtidigt som det var viktigt att inte"sörja som hedningarna, dvs. som de vilka saknade löftet om evigt liv". ${ }^{83}$ Hon lyfter även fram en annan orsak till den förnuftiga sorgen:

Dessutom kunde själva sörjandet tolkas som bristande förtröstan på Gud och därmed resultera i att den efterlevande miste sin egen möjlighet till evigt liv. Brist på förtröstan gick emot instruktionerna om konsten att leva och kunde ytterst leda till att en människa sörjde sig till helvetet. Sorgen måste därför vara måttlig. ${ }^{84}$

I detta binds reglerna för det religiösa samman med dem för värdighet och heder. Denna syn på sorgeprocessen anas framför allt i de anhörigas försök att trösta, som jag skriver mer om i följande avsnitt, men också i deras förmaningar gällande sörjandet som sådant. I ett brev till sondottern Gustava Ehrström, som kort innan hade mist sin styvmor Fredrika Ehrström, skriver Anna Maria Ehrström i836:

Men detta var ju en skickelse af vår Gudomliga vän som räknar våra dagar och leder oss til det bestämda målet af lefnaden, ja äfven med en huld Faders vishet styr allt till det bästa, men derjemte för att pröfva vår förtröstan och undergifvenhet för Hans vilja må vi då söka tröst hos Honom samt hemta styrka att öfvervinna sorgen och saknaden ja måtte sjelva sorgen rena själen och förädla våra hjertan på det vi engong efter pröfningarne här måge få för vår milde Förbarmares dyra förtjenst inngå uti de sälla Boningar där våra oförgätlige Vänner efter en kort skiljsmessa fira den Himmelskt ljufva återföreningens högtids glädje. ${ }^{85}$

82. Knipström, "Hvad är vårt lif när hälsan saknas?", kapitel 3; Anna-Maria Åström, "Sockenboarne". Herrgårdskultur i Savolax I790-1850, Helsingfors: Svenska litteratursällskapet i Finland I993, s. I3I-I32; J.F. Aminoff till A. Aminoff, I5/3 I822, Rilax samling, RA.

83. Arvidsson, "Psalmers tröst och stöd vid dödsfall", s. I39.

84. Ibid.

85. A.M. Ehrström till G. Ehrström, 9/5 1836, Borenius släktarkiv, RA. 
Även Gustava Ehrströms släkting, Emma Danielson, påminde henne om att i sorgen "ej knota öfver försynens skickelse Herren har väl försorg om sina lidande barn under denna korta vandring". ${ }^{86}$

Här syns åter tilltron till det gudomliga och tanken om att underkasta sig dess vilja. Joanna Bourke beskriver i sin studie av smärta hur man i det förflutna inom alla samhällsgrupper hyste en stark tro på att lidandet var skickat av Gud och något som man som god troende därför borde böja sig inför; detta skulle leda till en starkare moral och till att man belönades i livet efter detta. ${ }^{87} \mathrm{I}$ källmaterialet för denna studie målas sorgen ofta upp som en form av smärta och tilltron till Gud och idealet att underkasta sig denna smärta kan kanske även förklaras med det som Bourke hävdar: att man trodde att smärtan var en prövning skickad av Gud. Brevskrivarnas ordval då de beskrev sorgen, något vi ser exempel på i citaten, sammanhänger ofta med lidande och smärta: sorgen har "kostat på" eller "tärt på" hjärtan som "sönderslitits" eller "sårats". Sorgen var en del av livets förväntade lidande, något som man som god kristen skulle bära utan att klaga.

\section{TRÖSTENS K ÄNSLOREGLER}

I sin analys av I695 och I8Ig års psalmböcker nämner Arvidsson olika behov av tröst, som har koppling till dödens konsekvenser. Hon delar upp behoven i två kategorier: I) "allt som handlar om tillvaron efter döden", det vill säga "frågor om himmel och helvete, livet efter döden samt möjligheten till ett återseende", och 2) "de efterlevandes jordiska behov, livsvillkor och framtid", det vill säga "den hjälp som behövdes för anpassning till en ny livssituation". Hon menar också att det var varje god kristens plikt att försöka trösta den sörjande. ${ }^{88}$ Hon räknar upp fem tröstteman som förekommer i de psalmer hon analyserar:

[...] talet om himlen och det eviga livet, talet om ett framtida återseende i himlen för de döda, förklaringen att Jesus med sin död gjort

86. E. Danielson till G. Ehrström, I9/4 I836, Borenius släktarkiv, RA.

87. Bourke, The History of Pain, s. 88-I2I.

88. Arvidsson, "Psalmers tröst och stöd vid dödsfall", s. II9, I39. 
det eviga livet tillgängligt för alla, försäkran om beskydd och hjälp till änkor och faderlösa, beskrivningen av hur människan bör leva sitt liv. ${ }^{89}$

Arvidsson förtydligar också begreppet tröst, som hon ser som svårdefinierat. I dag betyder ordet oftast "emotionell lindring", men tidigare innefattade det "såväl lindring som tillit/förtröstan och stöd". Stödet kunde även innebära ekonomiskt stöd för att de efterlevande som påverkades av dödsfallet skulle klara sig. Detta gällde framför allt om maken i familjen dog. ${ }^{90}$

Av materialet för denna artikel framgår att ett viktigt inslag $i$ trösten var de kondoleansbrev som skrevs till de sörjande och som även kallades "klagoskrifter", för att använda Eva Mathilda Aminoffs kusin Johanna Fredrika Lovisa Armfelts ord. ${ }^{91} \mathrm{I}$ dem lyfts sådant som handlar om tillvaron efter döden fram. Ett exempel på den praktiska formen av stöd har berörts tidigare, i beskrivningen av hur Selma Augusta Europaeus och hennes mamma erbjöd hjälp åt änkan Aurora Boldt.

De brevskrivare som jag har analyserat använde tröstbilder av samma typ som förekommer i psalmböckerna. Psalmerna hade en viktig plats i människornas liv och var ett självklart inslag i de ritualer som omgärdade döden. De sjöngs av dem som var närvarande vid dödsbädden och likaså under begravningarna. I sitt brev till sin sondotter frågar till exempel Anna Maria Ehrström vilka psalmer som sjöngs på hennes styvmors begravning. ${ }^{92}$ Man kan anta att psalmerna och kyrkans bild av tröst hade ett starkt inflytande på människorna också i deras egna försök att trösta. Psalmerna och den kristna läran erbjöd de "rätta" sakerna att säga till sörjande, ord som var lätta att ta till sig. Psalmerna integrerades som en del av känslokollektivet i form av kondoleansbrevens känsloregler.

Det första temat i Arvidssons analys, himlen och det eviga livet, är det vanligaste och förekommer i alla kondoleansbrev. Det hänger starkt samman med analysens andra tema, utsikten att en gång få

89. Ibid., s. I36.

9o. Ibid., s. I24, I37.

9I. J.F.L. Armfelt till E.M. Aminoff, 9/4 I815, Rilax samling, RA.

92. A.M. Ehrström till G. Ehrström, 9/5 I836, Borenius släktarkiv, RA; Arvidsson, "Psalmers tröst och stöd vid dödsfall", s. I42. 
återförenas med de döda i ett liv efter detta. I de brev jag studerat uttrycks denna tanke i en förhärligande ton och med hjälp av många känslouttryck. Till exempel skrev Eva Mathilda Aminoffs bror, Gustaf Adolf Bruncrona, den I6 mars I8I5 följande i ett försök att trösta systern efter att hennes tre döttrar gått bort:

Medge att den tanken är ljuf att efter den oroliga och besvärliga resan genom lifvet komma i en hamn der du mötes af de käraste föremål; tänk dig trykt af dina smekande ungar Sophie i dina armar, Eva omkring din hals, Fredrika och Augusta på hvardera knät. ${ }^{93}$

Enligt Ariès började döden förhärligas under romantiken, det vill säga under slutet av 1700-talet och början av 180o-talet. ${ }^{94}$ Detta överensstämmer framför allt med det sätt på vilket de brevskrivare som jag analyserat målade upp livet efter detta som något att eftersträva. Inom ramen för en religiös övertygelse där man skulle leva på ett sätt som gjorde det möjligt att uppnå frälsning i döden - och dö på "rätt" sätt för att uppgå i det gudomliga - kan livet ses som en transportsträcka till något annat, något bättre. ${ }^{95}$ Det var en tanke som säkert behövdes för att hantera den i allt närvarande döden. Döden fungerade som en rening för människan, inte bara för den som dog utan också för dem som blev kvar. Bland andra Anna Maria Ehrström skrev till sin sondotter om reningen i sorgen:"må vi då söka tröst hos Honom samt hemta styrka att öfvervinna sorgen och saknaden ja måtte sjelva sorgen rena Själen och förädla våra hjertan." ${ }^{96}$ Dödsfall kunde ses som en rening för alla - om man bara levde, dog och sörjde på rätt sätt. Med de vackra föreställningarna om döden gjorde man den även till sin vän.

Samtidigt är många brevskrivare uppriktiga med att de har svårt att hitta rätt ord och uttrycker en övertygelse om att det är omöjligt att trösta den som hade förlorat en närstående. ${ }^{97}$ Som tidigare nämnts

93. G.A. Bruncrona till E.M. Aminoff, $\mathrm{I6} / 3$ I8I5, Rilax samling, RA.

94. Ariès, L'homme devant la mort 2 , kapitel to "Le temps des belles morts" [Den vackra dödens tid], s. II9-I83, särskilt I82-I83.

95. Werner,"Ars moriendi i kampen om det'goda' samhället", s. I49.

96. A.M. Ehrström till G. Ehrström, 9/5 1836, Borenius släktarkiv, RA.

97. Till exempel J.F.L. Armfelt till E.M. Aminoff, 9/4 I8I5, Rilax samling, RA och E. Danielson till G. Ehrström, I9/4 I836, Borenius släktarkiv, RA. 
krävde konventionerna inte heller att de närstående skulle kunna trösta, utan trösten kunde bara uppnås genom att man vände sig till Gud. Det framgår av breven där den sörjande ofta uppmanas att vända sig till Herren för att få tröst. Ett exempel hittas i Anna Maria Ehrströms ord till sin sondotter: "min egen Gustava misströsta ej bed om hjelp och bistånd hos Honom som aldrig öfvergifver den lidande värnlöse, måtte Du uti Religionen söka tröst samt mod och styrka." ${ }^{88}$

Något annat som hänger samman med trösttemat är att skribenterna målar upp en bild av hur bra de avlidna har det i livet efter detta."[L]åtom oss då ej missunna dem den glädjen att vara friade från en värld", skrev till exempel Gustaf Adolf Bruncrona år I8ı 8 till Eva Mathilda Aminoff med syftning på hennes döda barn. ${ }^{99}$ Enligt detta borde Eva Mathilda vara tacksam över att hennes barn kom "enkelt" undan; de dog innan de hann uppleva livets lidande och sorger. Men den bild som målas upp kan också vara ett uttryck för den uppfattning som Arvidsson nämner, att dödsdagen egentligen sågs som människans födelsedag i det himmelska livet. Med tanke på detta borde man snarare glädjas för den dödas skull och söka tröst för sin egen saknad hos Gud. ${ }^{100}$

Livet efter detta och tanken på att få återförenas med nära och kära efter döden är de två vanligaste trösttemana i de brev som jag analyserat, och framstår därmed som de starkaste känsloreglerna för kondoleansbreven. De andra temana, förklaringen att Jesus med sin död gjort det eviga livet tillgängligt för alla, beskrivningen av hur människan bör leva sitt liv och försäkran om att änkor och faderlösa ska beskyddas och hjälpas, förekommer inte lika ofta. Samtidigt kan temana anses ingå i brevskrivarnas allmänna föreställningar om det gudomliga, som omfattar förtröstan och tillit till Herren och idealet att man bör sörja med förnuft och undergivenhet. Beskydd och hjälp som de efterlevande fått nämns i korta meningar, som i ett brev av Anna Maria Ehrström där hon skriver: "Gudi lof, Hans Faderliga omsorg för de många värnlöse [barnen] hafve vi redan erfarit genom ädla vänners och goda anhöriges deltagande uti deras omvårdnad.”101

98. A.M. Ehrström till G. Ehrström, 9/5 I836, Borenius släktarkiv, RA.

99. G.A. Bruncrona till E.M. Aminoff, II/ro I8I8, Rilax samling, RA.

ıoo. Arvidsson, "Psalmers tröst och stöd vid dödsfall", s. I39.

ıог. A.M. Ehrström till G. Ehrström, 9/5 1836, Borenius släktarkiv, RA. 
De brev som analyserats i denna studie ger uttryck för både sorg och tröst och präglas i hög grad av en gudomlig förtröstan och tilltro till försynen. Skribenterna uttrycker emotioner som de kopplar till sorgen med hjälp av starka känslouttryck, och som nästan făr den att höras genom brevpappret. För skribenterna var döden en självklar del av livet. De uttryckte en förhärligande syn på den i enlighet med romantikens ideal och uttryckte en tilltro till försynen - för dem var det Gud som styrde över liv och död. Det framkommer att läkare tillkallades och att "[i] ngen skötsel fattades", ${ }^{102}$ men när allt kom omkring låg livet i Guds händer.

Som Ulla Ijäs konstaterar var stora känslor en del av brevens konventioner, samtidigt som de som hörde till societeten förväntades kunna behärska sina känslor. Denna paradox syns i brevmaterialet genom att sorgen uttrycks med starka känslouttryck, samtidigt som det framgår att skribenterna ansåg det viktigt att undvika för stark och långvarig sorg. En sådan kunde vara skadlig för hälsan och även gå emot den religiösa övertygelsen att"man måste med undergifvenhet emottaga försynens Beslut" 103 och tron på att det som skedde var det bästa. Döden innebar den slutgiltiga reningen, det vill säga frälsningen. Känsloreglerna förespråkade en förnuftig och måttlig sorg, samtidigt som språkets starka beskrivningar och uttryck kan ses som ett inslag i känsloreglerna: dels var det så här man förväntades uttrycka sorg, dels var det ett sätt att överbrygga det stora fysiska avståndet mellan avsändare och mottagare och stärka känslan av en delad erfarenhet.

Trösten sökte man inom den närmsta kretsen, eftersom man var säker på att alla kände "deltagande i Vänners lidande". ${ }^{104}$ Samtidigt fanns det en allmän uppfattning om att människor inte kunde trösta. Däremot kunde man uttala de rätta orden för att styra den sörjande mot det gudomliga och där söka sin tröst, något som är förenligt med Ann-Sofie Arvidssons analys av de tröstteman som syns i psalmböckerna från I695 och 1819. De teman som hon identifierar i psalmerna

I02. C.F. Rotkirch till G. von Kothen, 22/4 I8I9, von Kothens släktarkiv, RA. I03. Ibid.

I04. C.F. Rotkirch till G. von Kothen, 23/Io I8I9, von Kothens släktarkiv, RA. 
återkommer i de här analyserade breven. Man kan anta att psalmerna var en så självklar del av brevskrivarnas liv att de inspirerades av dem när de försökte trösta varandra, och att psalmerna därmed utgjorde en del av känsloreglerna. De teman som oftast förekom i samband med tröst var det eviga himmelska livet och Guds vilja. Man ansåg att Gud har en tanke med allt han gör, och att detta är det bästa med tanke på människan och det framtida återseendet i det eviga livet.

De känsloregler som avspeglas i breven präglades av religionen, av värdighet och heder samt av ett språk som markerade den samhällssfär som brevskrivarna tillhörde - och som därmed förenade avsändaren och mottagaren i sorgen. Reglerna varierade dock beroende på vem som var brevets mottagare och här spelade faktorer som rang och ålder in. De mest känslosamma breven skrevs till mottagare som var av samma rang och tillhörde samma generation. Inom en familj kunde det därmed finnas flera parallella känslokollektiv, och ytterst avgjordes reglerna för dessa av vem som skribenten föreställde sig att hen skrev till. 